\title{
Inmate Legal Information Requests Analysis: Empirical Data to Inform Library Purchases in Correctional Institutions
}

Kimberli Morris Kelmor

Penn State Law, kam59@psu.edu

Follow this and additional works at: https://elibrary.law.psu.edu/library_faculty

Part of the Legal Writing and Research Commons

\section{Recommended Citation}

Kelmor, Kimberli Morris, "Inmate Legal Information Requests Analysis: Empirical Data to Inform Library Purchases in Correctional Institutions" (2016). Law Library Faculty Works. 17.

https://elibrary.law.psu.edu/library_faculty/17

This Article is brought to you for free and open access by Penn State Law eLibrary. It has been accepted for inclusion in Law Library Faculty Works by an authorized administrator of Penn State Law eLibrary. For more information, please contact ram6023@psu.edu. 


\section{Inmate Legal Information Requests Analysis: Empirical Data to Inform Library Purchases in}

\section{Correctional Institutions}

The introduction of legal content to Google Scholar made United States case law and law journal articles accessible to an unprecedented extent. With case law freely available and accurate bibliographic information for articles, could Google Scholar be accurate and complete enough for correctional institutions to forgo purchasing either print publications or fee-based services for these materials? This article empirically assesses whether Google Scholar can reliably answer the questions of inmates in a correctional facility, the Baltimore City Detention Center. As a comparison, the same questions are tested in Westlaw Correctional, a subscription database marketed to correctional institutions.

\section{INTRODUCTION}

In 2009, Google unveiled the legal documents component of Google Scholar. This opened up a new source of United States case law for those needing free access to the law. To some extent, case law has been on the Internet since the early 1990 s. $^{1}$ However, it was scattered across multiple sites, was jurisdictionally incomplete, and even the best website had only recent decisions. ${ }^{2}$ Google Scholar's legal documents addition also included law review articles—while not always full text, it provided at least a full bibliographic citation and a brief excerpt. This was enough for users to request the specific article from their local library via interlibrary loan. Google Scholar provides a single engine to search both law review articles

\footnotetext{
${ }^{1}$ Legal Information Institute, About the LII / LII / Legal Information Institute (2014), available at https://www.law.cornell.edu/lii/about/who_we_are. ${ }^{2}$ Legal Information Institute, Legal Information Institute at Cornell Law School, Internet Archive (2009), available at https://web.archive.org/web/20090116015452/http://www.law.cornell.edu/.
} 
and opinions from all U.S. jurisdictions, as well as some fairly sophisticated search tools. For example, it is straightforward for a researcher to locate the right case by entering a case name and just a little bit of context. Selecting the "how cited" link of a given document yields the cited portion of the original document within the context of other documents that refer to it, which is another way for the searcher to be certain they have the right case. It also provides a selection of related documents.

767 a2d 844 - Google Scholar

Web Images Videos Maps News Shopping Gmail more v 1) My Account | Sign out

Google scholar 167 a2d 844

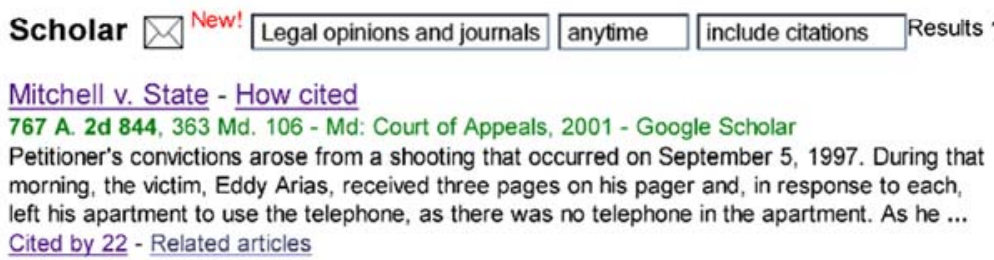

Figure 1. Mitchell v. State in Google Scholar Search

Google and the Google logo are registered trademarks of Google Inc., used with permission. 
Mitchell v. State, 767 A. 2d 844 - Md: Court of Appeals 2001 - Google Scholar

Web Images Videos Maps News Shopping Gmail more

| My Account | Sign out

Google scholar 767 a2d 844

\begin{tabular}{|c|c|c|c|}
\hline View this case & How cited & \multicolumn{2}{|c|}{ Mitchell v. State, 767 A. 2d 844 - Md: Court of } \\
\hline \multicolumn{3}{|c|}{ How this document has been cited } & Cited by \\
\hline \multirow{2}{*}{\multicolumn{3}{|c|}{$\begin{array}{l}66 \text { In Mitchell, we acknowledged our decision in Burch and observed again } \\
\text { "that second degree murder embraced a killing accompanied by any one } \\
\text { of at least three alternative states of mind...[ie,] killing another person } \\
\text { with the intent to inflict such serious bodily harm that death would be the } \\
\text { likely result [.]" 99 } \\
\text { - in Thornton v. State, } 2007 \text { and } 7 \text { similar citations }\end{array}$}} & $\begin{array}{l}\text { Clemons v. State } \\
896 \text { A. 2d } 1059-\text { Md: Court of } \\
\text { Appeals } 2006\end{array}$ \\
\hline & & & $\begin{array}{l}\text { Judicial Exploitation of Mens Rea } \\
\text { Confusion, at Common Law and } \\
\text { Under the ... }\end{array}$ \\
\hline \multirow{2}{*}{\multicolumn{3}{|c|}{$\begin{array}{l}\text { 66 -finding that conspiracy to commit the intent to kill form of second } \\
\text { degree murder is not a crime in Maryland "" } \\
\text { - in Goldsberry v. State. } 2008 \text { and } 3 \text { similar citations }\end{array}$}} & R Batey - Ga. St. UL Rev., 2001 \\
\hline & & & $\begin{array}{l}\text { Hudson v. State } \\
832 \text { A. 2d } 834-\text { Md: Court of Special } \\
\text { Appeals } 2003\end{array}$ \\
\hline \multirow{2}{*}{\multicolumn{3}{|c|}{$\begin{array}{l}66 \text { "The element that distinguishes this form of second degree murder from } \\
\text { first degree murder is that of deliberation and premeditation. For murder } \\
\text { 'to be "deliberate" there must be a full and conscious knowledge of the } \\
\text { purpose to kill; and to be "premeditated" the design to kill must have } \\
\text { preceded the killing by an appreciable length of time, that is, time enough } \\
\text { to be ...." } \\
\text { - in Bryant v. State, } 2006 \text { and } 2 \text { similar citations }\end{array}$}} & $\begin{array}{l}\text { B. SIFRIT v. State } \\
857 \text { A. 2d } 88-\text { Md: Court of Appeals } \\
2004\end{array}$ \\
\hline & & & $\begin{array}{l}\text { Bryant v. State } \\
\text { 900 A. 2d } 227-\text { Md: Court of Appeals } \\
2006\end{array}$ \\
\hline \multirow{3}{*}{\multicolumn{3}{|c|}{$\begin{array}{l}66 \text { Given the symmetry between the mens rea required for premeditated } \\
\text { first degree murder and conspiracy to commit murder, we are satisfied } \\
\text { that the trial court adequately instructed the jury, and that appellant's } \\
\text { conviction for conspiracy to commit first degree murder was not the } \\
\text { product of an instruction that would allow the jury to convict on the basis } \\
\text { of a lesser degree of ..., } \\
\text { - in Hudson v. State. } 2003 \text { and } 2 \text { similar citations }\end{array}$}} & all 22 citing documents n \\
\hline & & & Related documents \\
\hline & & & $\begin{array}{l}\text { B. SIFRIT v. State } \\
857 \text { A. 2d } 88-\text { Md: Court of Appeals } \\
2004\end{array}$ \\
\hline
\end{tabular}

Figure 2. Mitchell v. State, "how cited" tab

Google and the Google logo are registered trademarks of Google Inc., used with permission.

Many hailed this new resource as a great leap forward in access to the law for pro se

litigants and for others who could not afford services such as Lexis or Westlaw. ${ }^{3}$ Still, no one

seriously suggested Google Scholar as an alternative for academic law libraries, law firm

libraries, or even solo practitioners. Early on, there were questions of its reliability and

usefulness for research in such settings. ${ }^{4}$

\footnotetext{
${ }^{3}$ Kyle K. Courtney, Commentary: Google's free legal research database a welcome addition, Massachusetts Lawyers Weekly, Dec. 28, 2009.

${ }^{4}$ Diana Smith, North Carolina law librarians take cautious stance on Google Scholar, NC Lawyers Weekly, Nov. 30, 2009, at 1.
} 
Seven years later, few question its reliability anymore. However, usefulness is a function of both the resource itself and the context in which it is used. Having recently finished two years of employment at the Baltimore City Detention Center (BCDC), this author wanted to know how reliable and useful Google Scholar would be in fulfilling legal information requests from BCDC inmates. Since BCDC did have a subscription to Westlaw Correctional, the same questions would be researched in that database to provide a comparison.

\section{THE STATE OF THE LITERATURE}

Correctional law libraries are of concern to several different professions, as is reflected in the literature about them. Legal scholarship, law librarianship, librarianship, and correctional literature all address the topic to some extent. From the legal and law library perspectives, almost everything is driven by the two major cases: Bounds v. Smith, ${ }^{5}$ which held prisoners had to be furnished with adequate law libraries or adequate legal assistance; and Lewis v. Casey, ${ }^{6}$ which held there is no free standing right to a library and encouraged experimentation as to what could provide reasonable access for inmates to the courts. According to research by Sabath and Payne there are now several methods in use by prisons to provide access to the courts, with many prisons using multiple methods. Despite the Lewis ruling that there is no right to a library, the majority of prisons still use libraries as their preferred method of supporting access to the courts. ${ }^{7}$

\footnotetext{
${ }^{5}$ Bounds v. Smith, 430 U.S. 817 (1977).

${ }^{6}$ Lewis v. Casey, 518 U.S. 343 (1996).

${ }^{7}$ Michael J. Sabath and William Payne, Providing Inmate Access to the Courts: U.S. Prison Strategies for Complying with Constitutional Rights, 92 The Prison Journal 45 at 51, (2012). Typical methods used by institutions include supervised law students, on-line access to Lexis or Westlaw, CD ROM legal resources, legal assistance classes, jailhouse lawyers, and legal collections among others.
} 
As demonstrated in Chart 1 below, these cases did raise interest in the issue as

evidenced by small surges in the number of related articles published following the decisions.

One of the seminal works in this area is Morris Cohen's Reading Law in Prison. ${ }^{8}$ This is the first instance of advice from law librarians as to what a correctional law library collection should contain. O. James Werner, another of the early scholars in this field, wrote several works critical to the development of law library services to inmates including, among others, The Present Legal Status and Conditions of Prison Law Libraries ${ }^{9}$ and the Manual for Prison Law Libraries. ${ }^{10}$ In addition to those early works, Camilla Tubbs ${ }^{11}$ analyzes the existence and implications of a switch from print to electronic research and also provides a more extensive literature review for those interested in this topic. Jonathan Abel ${ }^{12}$ advocates for correctional law libraries to turn away from justifying themselves under the rubric of reasonable access to the courts, and he discusses the extent to which technology could affect that transition.

With this article's focus on legal research, the legal/law librarian perspective is the natural focus. That perspective has as its audience lawyers, legal scholars, and law librarians. But, there are few law librarians that run correctional libraries. A detailed review of the general library and the correctional literature are beyond the scope of this article. However, a brief, purely numeric, assessment both answers and raises questions about the law librarian

\footnotetext{
${ }^{8}$ Morris Cohen, Reading Law in Prison, 48 The Prison Journal 21-27; (Spring-Summer 1968).

${ }^{9}$ O. James Werner, Present Legal Status and Conditions of Prison Law Libraries, 66 Law Libr. J. 259 (1973).

10 O. James Werner, Manual for Prison Law Libraries (F.B. Rothman 1978).

${ }^{11}$ Camilla Tubbs, Electronic Research in State Prisons, 25 Legal Reference Services Q. 13 (2006).

12 Jonathan Abel, Ineffective Assistance of Library: The Failings and the Future of Prison Law Libraries, 101 Geo. L.J. 1171 (2012-2013).
} 
perspective versus the other perspectives. For this assessment, this author ran searches in the following indexes:

- Index to Legal Periodicals and Books (ILPB)

- $\quad$ LegalTrac (LT)

- $\quad$ Library and Information Science Abstracts (LISA)

This author designed the searches to limit hits to articles that explicitly mention correctional law libraries in either the subject field or abstract field. The exact searches were:

ILPB abstract("prison library") OR abstract("jail library") OR abstract("correctional library")

ILPB descriptor("Prison libraries") OR descriptor("Prison libraries -- Law \& legislation")

LT subject("prison libraries")

LISA abstract("prison library") OR abstract("jail library") OR abstract("correctional library")

LISA subject(prison libraries) AND subject(law OR legal) 


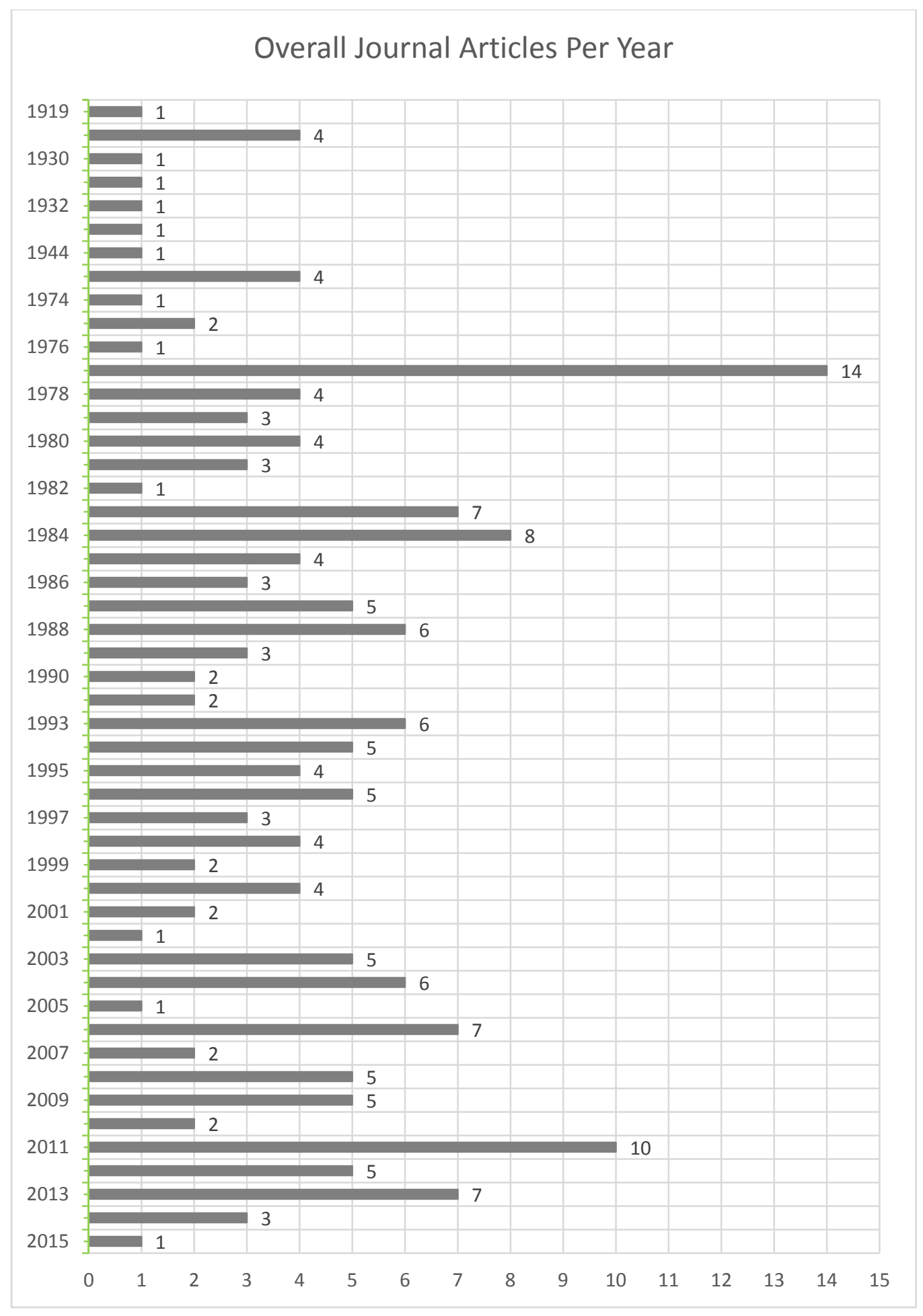

\section{Chart 1. Overall Journal Articles by Year}

Chart 1 displays a chart of all the articles returned from the searches by year. Because the majority of the journals represented were general library journals, it is interesting to see that 
Bounds ${ }^{13}$ was felt throughout the general correctional library literature. Also interesting is that there is a much smaller increase in journal articles after the other landmark case, Lewis. ${ }^{14}$ Interpretations of that can vary, but this author believes that society as a whole wasn't as interested in prisons and their libraries in the 1990s as it had been in the 1970s.

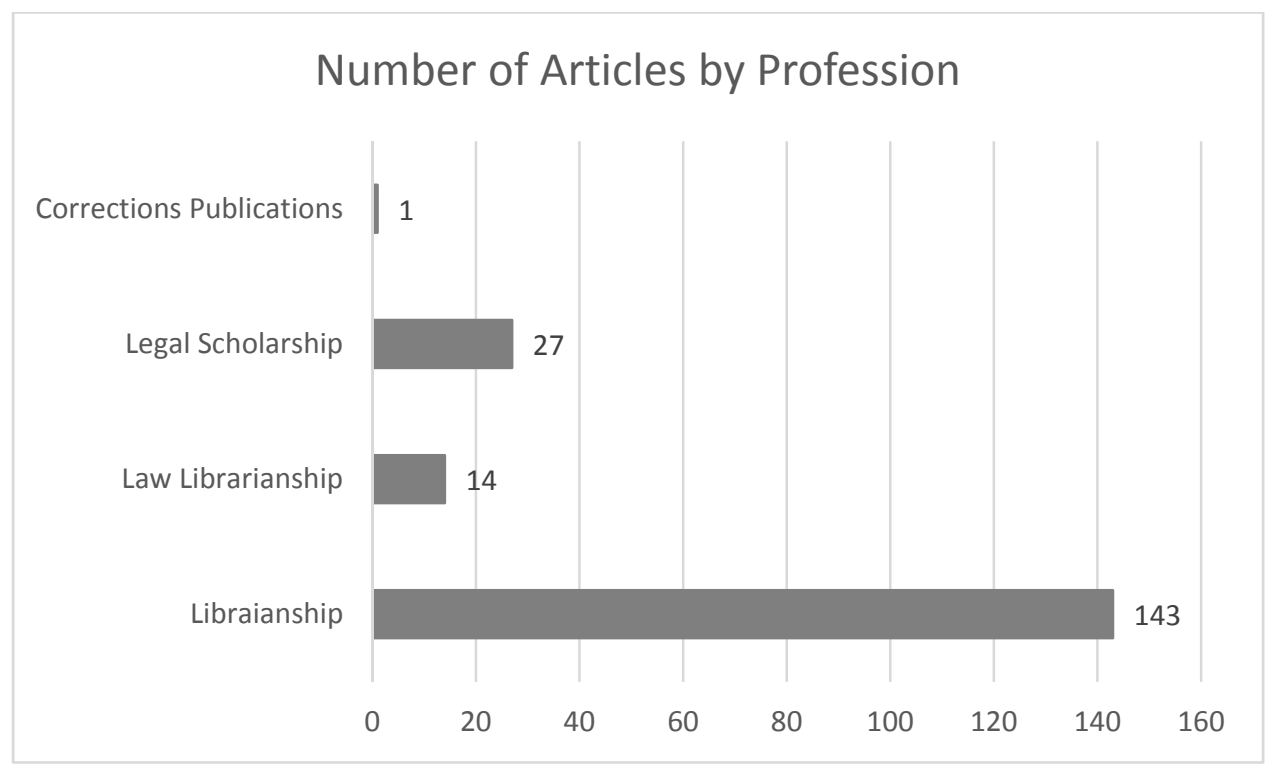

\section{Chart 2. Number of Articles by Profession}

Chart 2 shows the number of articles by the profession of the journals in which they appeared. Note that this is not the profession of the author of the article in question, but rather it is the profession of the journal. For example, law librarians write many of the articles in law reviews. This author chose to use profession of the journal because it most directly corresponds with the audience targeted. The vast majority of the articles examined targeted librarians, followed by law librarians and legal scholars. While this search was not exhaustive, it is somewhat disturbing that only one article explicitly targeted the corrections profession. These

\footnotetext{
${ }^{13}$ Bounds, supra n.5, passim.

${ }^{14}$ Lewis, supra n.6, passim.
} 
are the people who run the facilities and make the decisions about providing law libraries to their inmates.

\section{THE LOCAL CONTEXT}

Prior to its closing in 2015 BCDC was a city correctional facility housing predominately defendants with some post-conviction inmates. ${ }^{15}$ The population was around 2,000 to 3,000 inmates on any given day and included around 100 juveniles being tried as adults, about 500 to 600 women, and about 1,400 to 2,400 men. It was a pre-trial facility, with a few postconviction inmates serving out a sentence of 1 year or less. The average length of stay was about 3 months, which is dramatically different from post-conviction prisons. ${ }^{16}$ The short-term and pre-trial nature of the facility impacts the kinds of legal requests received from inmates. Because of litigation specific to this facility, the typical legal analysis of Lewis and following cases are applicable only in principle but are not dispositive of the issue of whether and how much of a law library the facility had to provide. BCDC had a long line of law suits against it for inmate conditions and services, and the resulting consent decrees included a mandate that the facility must provide both general and law library services. ${ }^{17}$ To fulfill the role of a law library,

\footnotetext{
${ }^{15}$ While parts of the BCDC complex remain open, the men's detention center in the oldest parts of the building closed in 2015. Ovetta Wiggins, Baltimore Jail Now Empty, Wash. Post B03 (Aug. 28, 2015).

${ }^{16}$ Maryland Department of Public Safety \& Correctional Services, Facilities Master Plan (2013).

171993 Revised Consolidated Decree, (United States District Court for the District of Maryland). The procedural history of this case is best summarized by Judge Hollander, in Duvall v. O'Malley, Civ. Action No. ELH-94-2541, 2014 U.S. Dist. LEXIS 48093, 2014 WL 1379787, at *8 (D. Md. April 7, 2014): "The protracted litigation has a tortured procedural history. At several stages of the litigation, the parties entered into consent decrees, consent orders, and court-approved settlement agreements resolving various aspects of the case. These include a 1978 Consent Decree (ECF 423-1); a 1993 Consolidated Consent Decree (sometimes referred to as the '1993 Decree'), dated July 9, 1993 (ECF 423-2); [2] a 2002 Consent Order (ECF 423-3); a 2009 Partial Settlement Agreement ('PSA,' ECF 374-1), approved by Order dated April 6, 2010 (ECF 394); and a 2012 Partial Settlement Agreement Amendment ('PSA Amendment,' ECF 447-1, approved by Order dated May 9, 2012 (ECF 465). These decrees, orders, and agreements provided for continuing monitoring by plaintiffs and the Court with respect to certain aspects of the operation of $B C D C$ and the conditions of confinement at the facility."
} 
BCDC had a collection of state reporters, the annotated state statutes, the state legal encyclopedia, local and state court formbooks, and a variety of legal treatises. The library also subscribed to the Legal Information Packets services of the Maryland Correctional Education Libraries $^{18}$ and to Westlaw Correctional. For statutory and case law research, Westlaw Correctional ${ }^{19}$ was the resource of choice. BCDC had the online access version, which contained all state and federal primary law, most law review articles, and the state legal encyclopedia. Only library staff had access to this database; inmates could not access it directly.

At the time this author worked at BCDC, 2006 to 2008, the standard procedure was for each men's cell block to go to the library for a one-hour period at least once a week. During this hour, the inmates had access to the general library materials and could request legal materials. The women (collectively) had one hour once a week, and the juveniles rarely, if ever, chose to go to the library. It was logistically difficult to transport the women inmates to the library because of building layouts, so probably fewer than $10 \%$ of the women were able to physically go to the library. Even for the men's blocks, not everyone could come, and lockdown conditions could block all travel within the facility. The library offered an information request form (see Figure 3) to any inmate who could not go to the library.

\footnotetext{
${ }^{18}$ For a description of the Library Assistance to State Institutions (LASI) Legal Information Packet service see Appendix B in Brenda Vogel, The Prison Library Primer: A Program For The Twenty-First Century (Scarecrow Press 2009).

${ }^{19}$ Westlaw Correctional is a package of the Westlaw database that is specifically marketed to correctional facilities by emphasizing secure access and customization to the resources needed at that particular facility. http://legalsolutions.thomsonreuters.com/law-products/ practice/government/correctional-facilities (accessed August 20, 2015).
} 


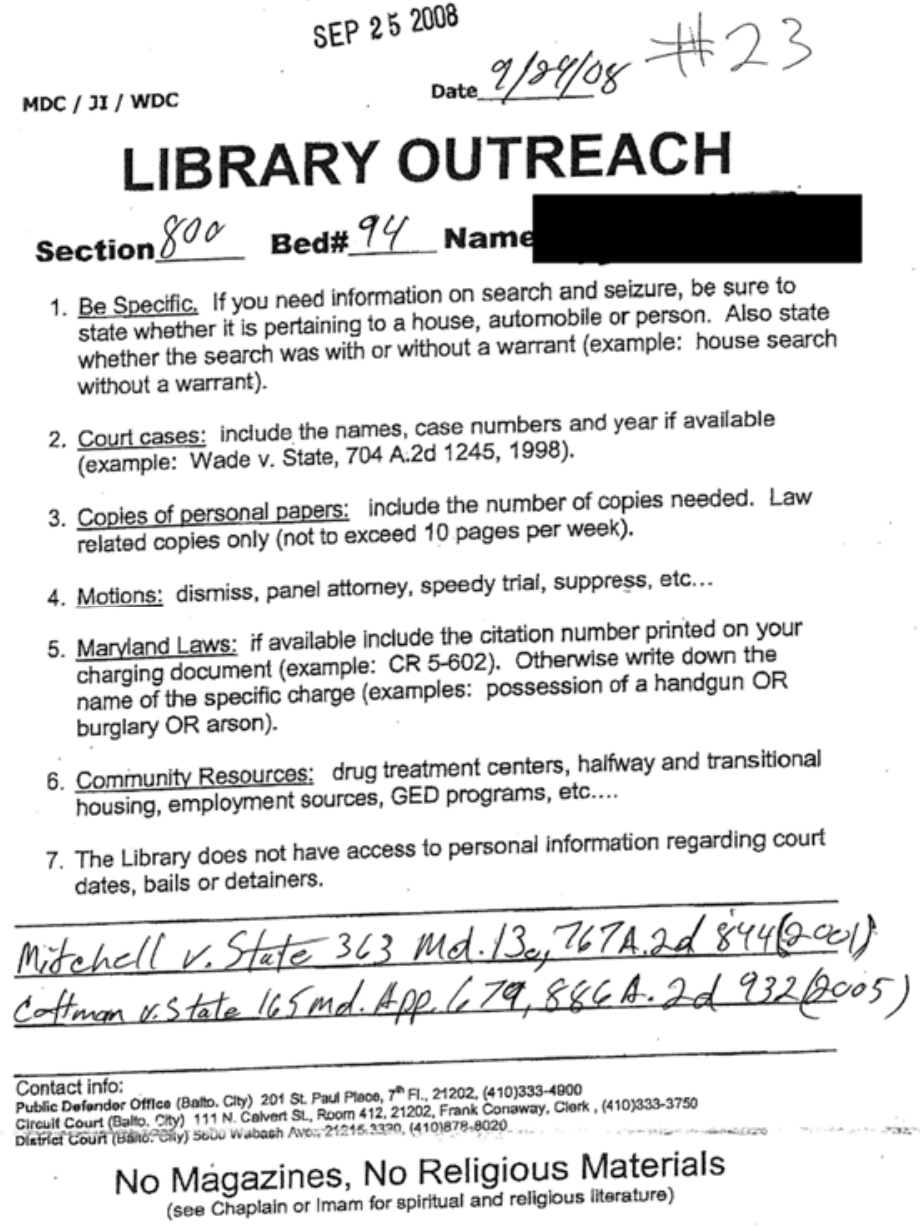

1. Be Specific. If you need information on search and seizure, be sure to state whether it is pertaining to a house, automobile or person. Also state whether the search was with or without a warrant (example: house search without a warrant).

2. Court cases: include the names, case numbers and year if available (example: Wade v. State, 704 A.2d 1245, 1998)

3. Copies of personal papers: include the number of copies needed. Law related copies only (not to exceed 10 pages per week).

4. Motions: dismiss, panel attorney, speedy trial, suppress, etc...

5. Maryland Laws: if available include the citation number printed on your charging document (example: CR 5-602). Otherwise write down the name of the specific charge (examples: possession of a handgun OR burglary OR arson).

6. Community Resources: drug treatment centers, halfway and transitional housing, employment sources, GED programs, etc...

7. The Library does not have access to personal information regarding court dates, bails or detainers.

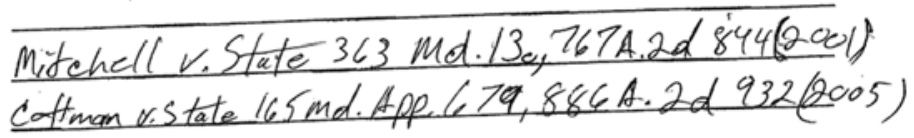

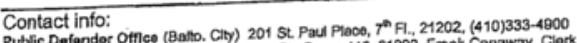

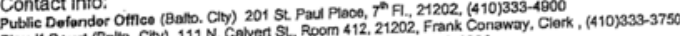

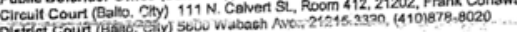

No Magazines, No Religious Materials

(see Chaplain or Imam for spirttual and religious Iitterature)

Figure 3. Inmate Information Request Form - requesting specific cases

Library staff typically completed these requests and returned the information to the inmate

within 24 hours. The majority of the library legal services were therefore mediated searches with the library information request form serving as a paper trail.

\section{METHODOLOGY}

This author analyzed a sample of 166 library information request forms provided by the BCDC library that the staff selected from the archives for the years of 2006 to 2010. The Penn State Office of Research Protections approved this author's analysis of inmate requests. Each form could have multiple questions, and splitting out each question yielded 558 discrete 
requests. Initially, this author planned for a simple two-step analysis: could library staff answer the question with (1) Westlaw Correctional and (2) Google Scholar? Testing the process on a handful of questions revealed a slightly more detailed analysis based on question type would be better. The eight question types were: cannot be determined, non-legal, motions or forms, legal treatise or encyclopedia, law journal article, cases, statutes, or a request to use a specific legal tool.

Westlaw has indexing and finding aids that good legal researchers can use to fill in missing citation information or to pick the correct case when ambiguous citation information results in a large number of hits. Because of that, this author attempted to answer all of the questions using Google Scholar first to lessen any learning effect from the Westlaw enhancements.

\section{RESULTS AND DISCUSSION}

Though the form does not indicate the requestor's identity, the housing unit specified indicated whether the question came from an adult male, adult female, or a juvenile. The analysis revealed the sample did not include any requests from juveniles. This was not very surprising given the small number of juvenile inmates. The sample also contained too few requests from women to be able to make a meaningful comparison by gender.

\begin{tabular}{|l|c|c|}
\hline Gender & Frequency & Percentage \\
\hline Female & 57 & 10.2 \\
\hline Male & 501 & 89.8 \\
\hline Total & 558 & 100.0 \\
\hline
\end{tabular}

Table 1: Basic Demographics

These were disappointing lacks in the sample. Based on this author's personal experience in 
the library, it seemed that women and juveniles request qualitatively different kinds of materials. Men typically focus on their criminal charges, but women seemed to request information about other issues such as divorce, child support, custody, domestic abuse, and restraining orders as well. That is painting with a broad brush, but it would have been useful to be able to verify whether the data supported that perception. If such differences exist, it could affect the kind of legal resources a library would purchase to fulfill the inmates' legal information needs. This is an area for follow-up study, which one might most effectively research at gender-specific or juvenile-only institutions.

\begin{tabular}{|l|r|c|}
\hline \multicolumn{1}{|c|}{ Question Type } & Frequency & Percentage \\
\hline Cannot be determined & 23 & 4.1 \\
\hline Non-legal & 70 & 12.5 \\
\hline Motion or form & 69 & 12.4 \\
\hline $\begin{array}{l}\text { Legal treatise or } \\
\text { encyclopedia }\end{array}$ & 173 & 31.0 \\
\hline Law journal article & 5 & 0.9 \\
\hline Case law & 69 & 12.4 \\
\hline Federal or state statute & 141 & 25.3 \\
\hline Specific legal tool request & 8 & 1.4 \\
\hline Total & 558 & 100.0 \\
\hline
\end{tabular}

Table 2: Question Classification

This author classified each question according to what type of information the inmate was requesting. The level of specificity of this eight category classification system allowed a meaningful comparison of the usefulness of each database. Twenty-three questions, $4.1 \%$ of the total sample, fell into the category of "cannot be determined." From this author's personal experience at $B C D C$, this was the case in many requests received through the information request form. While a reference interview might assist in clearing up these ambiguities, this was outside the scope of this analysis. Sixty-nine questions, representing $12.4 \%$ of the total sample, 
were requests for legal motions or other legal forms. At BCDC, library staff fulfilled all of these requests with formbooks published by the local court or state bar. Another 70 questions asked for non-legal information, such as requests for blank paper, photocopying services, general information, or leisure reading.

Legal questions only, count $=396$

\begin{tabular}{|l|r|r|r|r|}
\hline Research Resource & $\begin{array}{c}\text { Number of } \\
\text { questions } \\
\text { answered } \\
\text { partially }\end{array}$ & $\begin{array}{c}\text { Number of } \\
\text { questions } \\
\text { answered } \\
\text { completely }\end{array}$ & $\begin{array}{c}\text { Number of } \\
\text { questions that } \\
\text { could not be } \\
\text { answered }\end{array}$ & $\begin{array}{c}\text { Percentage of } \\
\text { questions that } \\
\text { each resource } \\
\text { could answer at } \\
\text { least partially }\end{array}$ \\
\hline Westlaw Correctional & 233 & 123 & 40 & $89.9 \%$ \\
\hline Google Scholar & 21 & 54 & 321 & $18.9 \%$ \\
\hline
\end{tabular}

Table 3: Overall Performance of Westlaw Correctional and Google Scholar for legal questions.

Simply separating all legal information requests from all non-legal questions creates the broadest categorization. Considering the legal information requests as a single group, the data firmly establishes that Westlaw Correctional is far better than Google Scholar. Even at this broadest level, if a correctional institution subscribes to no legal materials for inmates, either print or online, someone with access to Google Scholar could answer close to $20 \%$ of the sample of inmate legal information requests. Breaking down the analysis by categories of legal information reveals some of the reasons for the poor performance of Google Scholar.

Google Scholar fails completely with statutory information requests because it does not contain statutes. The four partial answers represented in Table 4 were instances in which a case happened to quote the full statute requested. 
Statutory Questions only, count $=141$

\begin{tabular}{|l|r|r|r|}
\hline \multicolumn{1}{|c|}{ Research Resource } & $\begin{array}{c}\text { Number } \\
\text { of } \\
\text { questions } \\
\text { answered } \\
\text { partially }\end{array}$ & $\begin{array}{c}\text { Number of } \\
\text { questions } \\
\text { answered } \\
\text { completely }\end{array}$ & $\begin{array}{c}\text { Number of } \\
\text { questions that } \\
\text { could not be } \\
\text { answered }\end{array}$ \\
\hline Westlaw Correctional & 70 & 56 & 15 \\
\hline Google Scholar & 4 & 0 & 137 \\
\hline $\begin{array}{l}\text { Freely Available US or State } \\
\text { code web site }\end{array}$ & 73 & 55 & 13 \\
\hline
\end{tabular}

Table 4: Performance by question type - Statutes

Still, that isn't a reliable source for the statute, because the code could be outdated by the time someone reads the case. Although Google Scholar fails in statutory research, freely available websites with either federal or state statutes could fill this particular gap. As far as retrieving the actual statutory section, the free sites work as well as Westlaw Correctional. These free sites contain the text of the statute only, without the case annotations and other research aids added by Westlaw.

Case Questions only, count $=69$

\begin{tabular}{|l|r|r|r|}
\hline Research Resource & $\begin{array}{c}\text { Number } \\
\text { of } \\
\text { questions } \\
\text { answered } \\
\text { partially }\end{array}$ & $\begin{array}{c}\text { Number of } \\
\text { questions } \\
\text { answered } \\
\text { completely }\end{array}$ & $\begin{array}{c}\text { Number of } \\
\text { questions that } \\
\text { could not be } \\
\text { answered }\end{array}$ \\
\hline Westlaw Correctional & 24 & 43 & 2 \\
\hline Google Scholar & 23 & 40 & 6 \\
\hline
\end{tabular}

Table 5: Performance by question type - Cases

Google Scholar is competitive with Westlaw Correctional in retrieving cases. Frequently, the inmates would request cases with the full citation (most often from an annotation in the statute section they received). Westlaw Correctional was slightly better than Google Scholar for retrieving cases when the citation was incomplete or wrong. Cases retrieved from Google Scholar can act as further finding tools to the extent that the opinions themselves cite other 
relevant cases. But, as with statutes, the value added by Westlaw in the form of headnotes and the Topic and Key Number System is unavailable in Google Scholar.

Law Review Request $=5$
\begin{tabular}{|l|r|r|r|}
\hline Research Resource & $\begin{array}{c}\text { Number } \\
\text { of } \\
\text { questions } \\
\text { answered } \\
\text { partially }\end{array}$ & $\begin{array}{c}\text { Number of } \\
\text { questions } \\
\text { answered } \\
\text { completely }\end{array}$ & $\begin{array}{c}\text { Number of } \\
\text { questions that } \\
\text { could not be } \\
\text { answered }\end{array}$ \\
\hline Westlaw Correctional & 4 & 0 & 1 \\
\hline Google Scholar & 2 & 0 & 3 \\
\hline
\end{tabular}

Table 6: Performance by question type - Law Review Articles

Requests for secondary source materials are further broken down into two categories:

(1) law review articles and (2) all other secondary source items such as treatises, legal

encyclopedias, legal dictionaries, etc. This author's personal experience in the BCDC library indicated that most requests for law review articles typically came from annotations in the statute sections that inmates received. With only five requests for articles, it is not possible to meaningfully assess whether that anecdotal perception is accurate. BCDC did not at that time have a specific interlibrary loan (ILL) agreement with any of the local law libraries. Such an arrangement would allow library staff to use Google Scholar to search by keyword or verify citations to articles, which they could then request through ILL. This would actually enable access to a greater number of law reviews because Westlaw Correctional's coverage does not include complete runs of journals. 
Secondary Source Legal Question count $=173$

\begin{tabular}{|l|r|r|r|}
\hline Research Resource & $\begin{array}{c}\text { Number of } \\
\text { questions } \\
\text { answered } \\
\text { partially }\end{array}$ & $\begin{array}{c}\text { Number of } \\
\text { questions } \\
\text { answered } \\
\text { completely }\end{array}$ & $\begin{array}{c}\text { Number of } \\
\text { questions that } \\
\text { could not be } \\
\text { answered }\end{array}$ \\
\hline Westlaw Correctional & 158 & 3 & 12 \\
\hline Google Scholar & 140 & 1 & 32 \\
\hline
\end{tabular}

Table 7: Performance by question type - Other Secondary Sources

For other secondary sources, Google Scholar isn't quite as competitive as the counts in Table 7 would suggest. The request forms typically ask for "information on" a given topic.

While technically any information on the topic would fill the request, realistically it is a

subjective call by the information provider as to whether they have completely or even partially

filled such a request. Both paid major legal databases and Google Scholar are less effective in the jail environment than carefully selected print treatises and practice aids.

Specific Finding Tool Request $=8$

\begin{tabular}{|l|r|r|r|}
\hline Research Resource & $\begin{array}{c}\text { Number } \\
\text { of } \\
\text { questions } \\
\text { answered } \\
\text { partially }\end{array}$ & $\begin{array}{c}\text { Number of } \\
\text { questions } \\
\text { answered } \\
\text { completely }\end{array}$ & $\begin{array}{c}\text { Number of } \\
\text { questions that } \\
\text { could not be } \\
\text { answered }\end{array}$ \\
\hline Westlaw Correctional & 0 & 8 & 0 \\
\hline Google Scholar & 0 & 0 & 8 \\
\hline
\end{tabular}

Table 8: Performance by question type - Other Specific Finding Tools

There is frequent discussion in both case law and the literature as to whether or not inmates are capable of using sophisticated research tools offered by commercial legal publishers. ${ }^{20}$ Anecdotally, this author remembers being surprised the first time she received

\footnotetext{
${ }^{20}$ See, e.g., Arturo A. Flores, Bounds and reality: lawbooks alone do not a lawyer make, 77 Law Libr. J. 275 (1985) and Camilla Tubbs, Electronic Research in State Prisons, 25 Legal Reference Services QuarterLy (2006).
} 
such a request. After the surprise wore off, she remained impressed with the way at least some inmates understood how the tools worked and used them to their best advantage.

SEP 252008 .

\section{LAW LIBRARY OUTREACH}

Section: 800 Bed\#31-A Name:

1. Be Specific. If you need information on search and seizure, be sure to state whether it is pertaining tò a house, automobile, or person. Also state whether the search was with or without a warrant (ex: house search without a warrant).

2. Court cases: include the names, case numbers, and year if available. (e.g. Wade v. Robb, 123 A2d 345, 1987.)

3. Copies of personal papers: include the number of copies needed (not to exceed 10 pages per week).

4. Motions: e.g. Dismiss due to Defective Charging Documents, Panel Attorney, Supress, Speedy trial, etc...

5. Maryland Laws: if available include the citation number printed on your charting document (e.g. CR 5-602, intent to distribute).

WE DO NOT HAVE ACCESS TO PERSONAL INFORMATION REGARDING COURT DATES, BAILS, DETAINERS, OR WHO YOUR ATTORNEY OR PAROLE OFFICER IS.

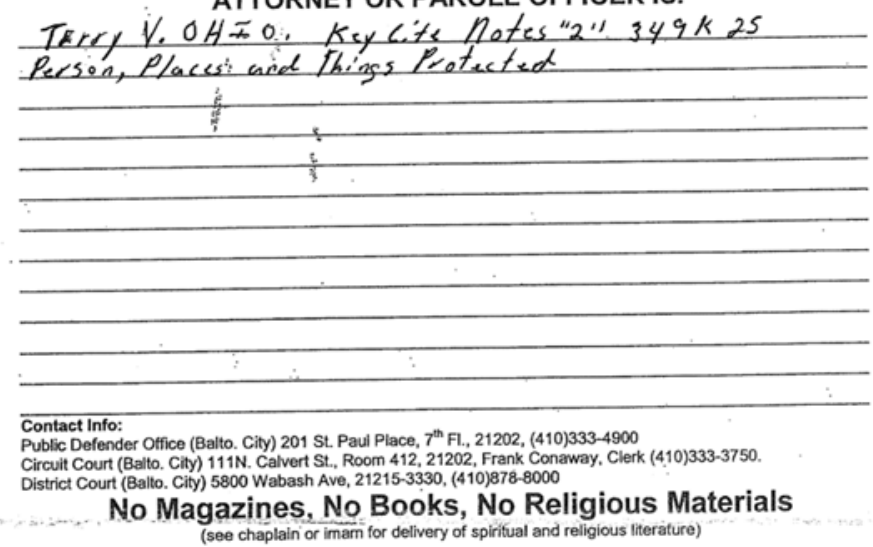

LEGAL INFORMATION REQUESTS ONLY

Figure 4. Inmate Information Request Form - specific search tool

Examples of these requests during this author's time at BCDC include: Shepardizing a case, searching Maryland case law for a Topic and Key Number found in an out-of-state case, and searching for additional law using a Criminal Code citation as the search term. This sample only contained eight such requests—seven requesting a Topic and Key Number search and two requesting KeyCite. Google Scholar, of course, completely failed at these requests while Westlaw Correctional filled them quite handily. 


\section{CONCLUSION}

Google Scholar on its own is not sufficient to provide the legal information needed by inmates in a pretrial correctional facility. It is, however, a readily available resource that library staff, with appropriate training, can use to reliably provide both cases and article citations needed by inmates. With correct citations in hand, it is possible to request document delivery from libraries that would otherwise be reluctant to handle inmate requests. Also, searching cases through Google Scholar as a first resort may allow the jail administration to structure its contract for resources like Westlaw Correctional to provide at least some cost savings. Further research, both in other jurisdictions and in facilities with larger numbers of women and juveniles, may reveal if those variables impact the usefulness of Google Scholar. 